\title{
Identification of a GCC transcription factor responding to fruit colour change events in citrus through the transcriptomic analyses of two mutants
}

Gabino Ríos ${ }^{1}$, Miguel A Naranjo ${ }^{1}$, María-Jesús Rodrigo² ${ }^{2}$ Enriqueta Alós ${ }^{1}$, Lorenzo Zacarías ${ }^{2}$, Manuel Cercós ${ }^{1}$, Manuel Talón ${ }^{*}$

\begin{abstract}
Background: External ripening in Citrus fruits is morphologically characterized by a colour shift from green to orange due to the degradation of chlorophylls and the accumulation of carotenoid pigments. Although numerous genes coding for enzymes involved in such biochemical pathways have been identified, the molecular control of this process has been scarcely studied. In this work we used the Citrus clementina mutants 39B3 and 39E7, showing delayed colour break, to isolate genes potentially related to the regulation of peel ripening and its physiological or biochemical effects.
\end{abstract}

Results: Pigment analyses revealed different profiles of carotenoid and chlorophyll modification in 39B3 and 39E7 mutants. Flavedo from 39B3 fruits showed an overall delay in carotenoid accumulation and chlorophyll degradation, while the flavedo of 39E7 was devoid of the apocarotenoid $\beta$-citraurin among other carotenoid alterations. A Citrus microarray containing about 20,000 cDNA fragments was used to identify genes that were differentially expressed during colour change in the flavedo of 39B3 and 39E7 mutants respect to the parental variety. The results highlighted 73 and 90 genes that were respectively up- and down-regulated in both mutants. CCGCC1 gene, coding for a GCC type transcriptional factor, was found to be down-regulated. CCGCC1 expression was strongly induced at the onset of colour change in the flavedo of parental clementine fruit. Moreover, treatment of fruits with gibberellins, a retardant of external ripening, delayed both colour break and CCGCC1 overexpression.

Conclusions: In this work, the citrus fruit ripening mutants 39B3 and $39 \mathrm{E} 7$ have been characterized at the phenotypic, biochemical and transcriptomic level. A defective synthesis of the apocarotenoid $\beta$-citraurin has been proposed to cause the yellowish colour of fully ripe 39E7 flavedo. The analyses of the mutant transcriptomes revealed that colour change during peel ripening was strongly associated with a major mobilization of mineral elements and with other previously known metabolic and photosynthetic changes. The expression of CCGCC1 was associated with peel ripening since CCGCC1 down-regulation correlated with a delay in colour break induced by genetic, developmental and hormonal causes.

\section{Background}

Citrus trees produce non-climacteric hesperidium fruits with outstanding agricultural and economic relevance. At the morphological level, citrus fruits consist of an

\footnotetext{
* Correspondence: talon_man@gva.es

${ }^{1}$ Centro de Genómica, Instituto Valenciano de Investigaciones Agrarias,

Carretera Moncada-Náquera km 4.5, 46113 Moncada (Valencia), Spain

Full list of author information is available at the end of the article
}

inner edible flesh (endocarp), an intermediate spongy layer (albedo or mesocarp) and an external coloured peel containing pigments and essential oils (flavedo or epicarp). Fruit development in oranges has been divided into three consecutive phases, characterized by a high rate of cell division but slow fruit growth during approximately two months after anthesis (phase I), a second phase of rapid increase in fruit size due to cell 
enlargement and water accumulation (phase II), and finally a phase of very reduced rate of fruit growth and ripening (phase III) [1].

Citrus fruit maturation shows specific features in flesh and flavedo tissues. Whereas internal maturation in the flesh is accompanied by an increase in the content of solutes and a decrease in acidity, external maturation is typically characterized by a change in colour from green to orange caused by the concomitant catabolism of chlorophylls and the synthesis of carotenoids [2-4]. Under specific environmental conditions, the changes in colour occurring in flavedo may be reversible and are affected by endogenous factors, such as nutrients (sucrose and nitrogen) and phytohormones (gibberellins and ethylene) [5-7]. The biochemical pathways underlying these transformations of pigments have been partially elucidated. Ethylene-induced chlorophyllase activity and gene expression has been negatively related to chlorophyll content suggesting the involvement of the enzyme in colour breakdown of flavedo [8-10]. The characteristic orange colouration of oranges and mandarins is due to the accumulating carotenoids in chromoplasts, particularly oxygenated derivatives $(\beta, \beta$-xanthophylls) and several specific carotenoid cleavage products (apocarotenoids) [11]. Citrus genes coding for enzymes involved in the synthesis and modification of carotenoids have been previously isolated and their evolution during natural and ethylene-induced ripening described [12-16].

Despite such extensive analysis of the physiological and biochemical aspects of fruit external maturation, studies describing induced or natural mutants showing an altered pattern or timing of colour acquisition are scarce yet. Among them, the orange (Citrus sinensis L. Osbeck) mutant Pinalate produced yellow-coloured fruits due to an unusually high accumulation of linear carotenes instead of cyclic and oxygenated carotenoids. The mutant also exhibited reduced synthesis of ABA. However, the specific alteration of the carotenoid biosynthesis pathway in Pinalate is currently unknown [17]. The nan spontaneous mutation of 'Washington Navel' orange, as formerly characterized in our group, showed an abnormal brown colour in the ripe flavedo caused by a defective catabolism of chlorophylls. Transcript profiling indicated that a SGR-like (STAY$G R E E N)$ gene was expressed at lower levels in nan flavedo, suggesting that nan mutation could be associated to a $S G R$-like upstream regulatory factor [18]. Recently, the delay in fruit colouration displayed by the slow-ripening clementine mutant 'Tardivo' (Citrus clementina Hort. Ex Tan.) has been associated with altered expression of carotenoid biosynthetic genes and different sensitivity to the exogenous application of ethylene [19].
As part of a mutagenic approach to citrus functional genomics, our group established a collection of near 10,000 independent Citrus clementina mutants obtained by fast neutrons bombardment, which were expected to contain genomic deletions in hemizygous dosage. Two of these mutants, called 39B3 and 39E7, were molecularly characterized by array-Comparative Genomic Hybridization for the identification of deleted genes. The structure of 39B3 deletion, determined at the BAC resolution, contained more than 21 identified genes spanning a large genomic region [20]. Phenotypic evaluation for several consecutive years demonstrated that 39B3 and 39E7 mutants have a significant delay in external fruit colour break. In this work we complete the phenotypic characterization and provide the transcriptomic profiling of flavedo from these mutants.

\section{Results and discussion}

Delay of colour change in 39B3 and 39E7 mutants

Mutants 39B3 and 39E7 showing delayed fruit colour break for several consecutive years were obtained from a population of near 10,000 Citrus clementina plants mutagenized by fast neutrons irradiation. Fruits from 39B3 and 39E7 retained an appreciable greenish colour at the end of November, while fruits from the nonmutagenized parental (for simplification designated as clementine in this work) had already initiated the shift to orange at this time (Figure 1A). A previous structural analysis of the hemizygous genomic deletions found in these mutants reported large DNA lesions containing a high number of genes, but no evidences of overlapping regions in the 39B3 and 39E7 deletions were observed [20]. In order to characterize the nature of colour break alterations affecting these mutants, changes in flavedo colour index (CI) were measured throughout fruit development in both mutants. As shown in Figure 1B, flavedo $\mathrm{CI}$ in clementine followed a sigmoid curve shifting from negative (green colour) to positive values (orange colour), approximately at mid November. The pattern of colour change in 39B3 fruits showed a similar behaviour but with a delay of three-four weeks. In 39E7 mutants, however, CI increased at a slower rate (Figure 1B) and reached lower final values than the clementine and 39B3 plants (Figure 1C). These observations suggested that 39B3 and 39E7 mutations affect fruit external ripening in distinct ways; the 39B3 mutation causes a simple delay in flavedo colour change, while the 39E7 mutant is characterized by a reduced rate of colour acquisition leading to an unusual yellowish external appearance after full ripening.

Chlorophyll and carotenoids accumulation in the mutants In order to gain a deeper insight into the biochemical alterations affecting 39B3 and 39E7 mutants, total 


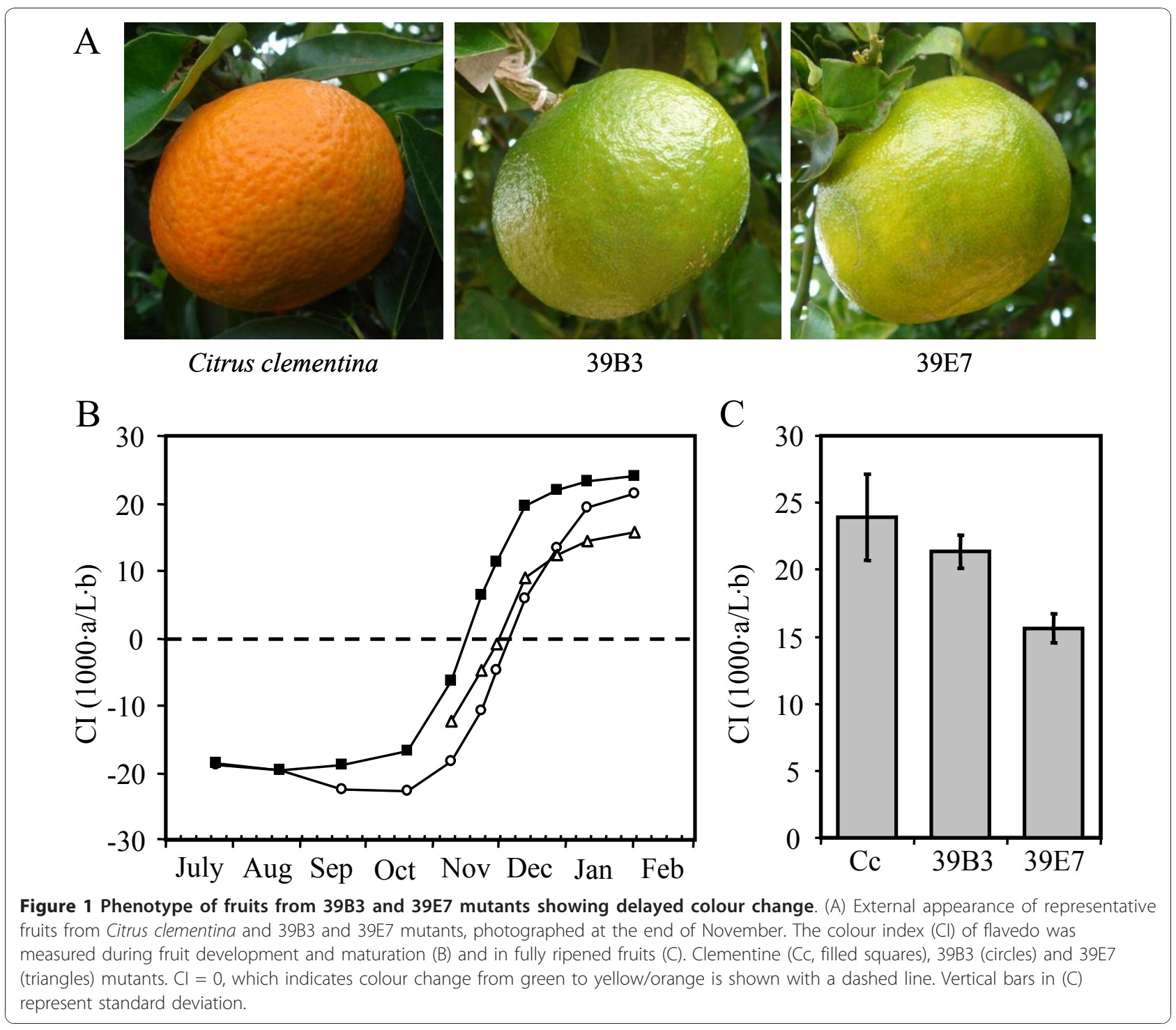

chlorophylls and total and individual carotenoids were determined in flavedo from both mutants and parental fruits at two different developmental stages: in November when colour differences with clementine were more evident (Figure 1A) and in January when all three genotypes had reached the final colouration.

Total chlorophyll pigments were four to five-fold more abundant in 39B3 and 39E7 than in the parental (Table 1 ), which suggests a slower chlorophyll catabolism or a general delay of maturation. These data were in close agreement with the greenish appearance of mutant fruits in November, while clementine fruits were already changing to orange (Figure 1A). No chlorophylls were however detected two months later, when the three genotypes showed an intense orange (clementine and 39B3) or yellowish (39E7) colouration. Total carotenoids were in 39B3 lower than in clementine in November as expected from the delayed colour break in this mutant, and also in January. On the contrary, 39E7 mutant showed a higher amount of carotenoids in November, but no significant statistical differences were observed with respect to the parental in January.

The profile of individual carotenoids obtained in the flavedo of clementine essentially coincided with previous reports in this variety, characterized by a reduction in $\beta, \varepsilon$-carotenoids and neoxanthin and an increase of specific $\beta, \beta$-xanthophylls during ripening [15]. In January, the 39B3 mutant exhibited a carotenoid profile very similar to that of the clementine. However, the pattern of pigment distribution in 39B3 in November differed significantly from the parental, showing lower percentages of phytoene, phytofluene and $\beta$-citraurin, and higher amounts of $\beta$-carotene, neoxanthin, $\alpha$-cryptoxanthin and lutein (Table 1), characteristics of chloroplastic tissues, in 
Table 1 Distribution of carotenoids and total carotenoid and chlorophyll content in flavedo from clementine and 39E7 and 39B3 mutants

\begin{tabular}{|c|c|c|c|c|c|c|}
\hline & \multicolumn{6}{|c|}{ Carotenoids (\% of total) } \\
\hline & \multicolumn{3}{|c|}{ November } & \multicolumn{3}{|c|}{ January } \\
\hline & Clementine & $39 \mathrm{E} 7$ & 39B3 & Clementine & $39 \mathrm{E} 7$ & 39B3 \\
\hline \multicolumn{7}{|l|}{ Carotenes } \\
\hline Phytoene & $9.7 \pm 2.8$ & $6.5 \pm 0.1$ & $1.6 \pm 1.8$ & $10.9 \pm 0.8$ & $7.8 \pm 2.0$ & $4.6 \pm 2.1$ \\
\hline Phytofluene & $1.9 \pm 0.7$ & $1.3 \pm 0.1$ & - & $1.8 \pm 1.5$ & $1.4 \pm 0.5$ & $1.1 \pm 0.1$ \\
\hline$\zeta$-Carotene & - & - & - & $0.2 \pm 0.1$ & - & - \\
\hline \multicolumn{7}{|l|}{$\beta, \beta$ Carotenoids } \\
\hline$\beta$-Carotene & tr. & $0.4 \pm 0.2$ & $0.9 \pm 0.1$ & $0.6 \pm 0.3$ & $0.5 \pm 0.2$ & $0.2 \pm 0.1$ \\
\hline$\beta$-Cryptoxanthin & $6.1 \pm 0.7$ & $10.3 \pm 0.7$ & $14.1 \pm 1.2$ & $11.1 \pm 2.3$ & $15.1 \pm 0.5$ & $13.5 \pm 2.0$ \\
\hline Zeaxanthin & $1.7 \pm 0.1$ & $2.1 \pm 0.1$ & $2.3 \pm 1.3$ & $0.4 \pm 0.2$ & $1.1 \pm 0.1$ & $0.7 \pm 0.1$ \\
\hline Anteraxanthin ${ }^{a}$ & $5.6 \pm 0.1$ & $8.0 \pm 0.5$ & $10.6 \pm 0.7$ & $7.7 \pm 0.7$ & $8.3 \pm 0.6$ & $9.7 \pm 0.8$ \\
\hline E-Violaxanthin & $8.1 \pm 0.3$ & $17.1 \pm 0.3$ & $10.1 \pm 1.1$ & $15.8 \pm 3.4$ & $17.0 \pm 1.3$ & $17.6 \pm 1.8$ \\
\hline 9-Z-Violaxanthin & $39.6 \pm 3.1$ & $37.7 \pm 0.3$ & $57.6 \pm 3.7$ & $36.2 \pm 4.0$ & $36.3 \pm 2.3$ & $36.0 \pm 1.8$ \\
\hline Neoxanthin & $9.6 \pm 0.6$ & $1.2 \pm 0.3$ & $13.0 \pm 0.6$ & - & - & - \\
\hline \multicolumn{7}{|l|}{ Apocarotenoids } \\
\hline$\beta$-Citraurin & $3.8 \pm 0.2$ & - & $1.7 \pm 0.3$ & $4.6 \pm 0.7$ & - & $4.0 \pm 0.3$ \\
\hline 8- $\beta$-Apocarotenal & $0.5 \pm 0.2$ & - & & - & - & - \\
\hline \multicolumn{7}{|l|}{$\beta, \varepsilon$ Carotenoids } \\
\hline$\alpha$-Cryptoxanthin & - & - & $4.0 \pm 0.4$ & - & - & - \\
\hline Lutein & $0.7 \pm 0.1$ & $1.5 \pm 0.1$ & $5.6 \pm 2.6$ & $0.6 \pm 0.5$ & $1.5 \pm 0.6$ & $1.0 \pm 0.1$ \\
\hline Unidentified & $6.4 \pm 0.6$ & $5.9 \pm 0.2$ & - & $4.2 \pm 0.2$ & $3.7 \pm 0.7$ & $5.3 \pm 1.0$ \\
\hline $\begin{array}{l}\text { Total carotenoid } \\
(\mu \mathrm{g} \cdot \mathrm{g}-1 \mathrm{FW})\end{array}$ & $54.7 \pm 3.1$ & $84.4 \pm 2.3$ & $38.7 \pm 3.2$ & $102.6 \pm 11.1$ & $88.9 \pm 14.2$ & $66.1 \pm 9.1$ \\
\hline $\begin{array}{l}\text { Chlorophylls } \\
\text { ( } \mu g \cdot g-1 \text { FW) }\end{array}$ & $11.0 \pm 6.6$ & $49.0 \pm 11.3$ & $47.5 \pm 1.6$ & - & - & - \\
\hline
\end{tabular}

Values are mean \pm SD of at least three measurements; ${ }^{\text {a }}$ sum of antheraxanthin and mutatoxanthin; - not detected; tr. traces.

good agreement with the delayed external colouration in $39 \mathrm{~B} 3$ fruit. Other $\beta, \beta$-xanthophylls more typical of chromoplastic citrus peel, as $\beta$-cryptoxanthin, anteraxanthin and $9-Z$-violaxanthin, were found in a percentage higher than expected, however the lower amount of total carotenoids in 39B3 indicated a roughly similar absolute accumulation of them in both 39B3 and clementine.

The carotenoid profile of 39E7 mutant showed common features in November and January. In both samples, the absence of the apocarotenoid $\beta$-citraurin $\left(C_{30}\right)$ was associated with a higher accumulation of the xanthophylls $\beta$-cryptoxanthin and zeaxanthin. This observation is of special significance because despite the relevant contribution of $\beta$-citraurin, a red-orange pigment, to the typical peel colour of oranges and mandarines [11,21], the specific cleavage reaction producing this $\mathrm{C}_{30}$-apocarotenoid has not been yet elucidated. The total absence of $\beta$-citraurin in fully ripened flavedo of 39E7 mutant suggests that such cleavage reaction could be impaired in this genotype, leading to its distinctive pale yellowish peel. The concomitant increase of $\beta$-cryptoxanthin and zeaxanthin in 39E7 might indicate a substrate-product relationship between them and $\beta$-citraurin, reinforcing previous suggestions $[11,12,21]$. Such alteration in the carotenoid biosynthesis pathway corroborates at the biochemical level colour-based observations on the different developmental defects affecting 39B3 and 39E7 mutants. However we cannot rule out the presence of multiple mutations in 39E7 leading to separate effects on colour break delay and carotenoid accumulation. Under this assumption, the observed delay in external colouration could be caused by the same locus in both mutants.

\section{Differential expression profiling in flavedo}

The availability of 39B3 and 39E7 mutants has been exploited to identify major factors involved in regulation of fruit maturation through the transcriptomic analysis of flavedo tissue from these mutants. We took advantage of a citrus cDNA microarray previously described [22] to perform large scale hybridization experiments comparing mRNA isolated from green flavedo of both mutants and clementine flavedo undergoing colour break collected the same day. After microarray hybridization and analysis, cDNAs showing a signal intensity more than double or less than half of control, under a P-value threshold of $10^{-5}$, were considered as differentially expressed genes. Signal 

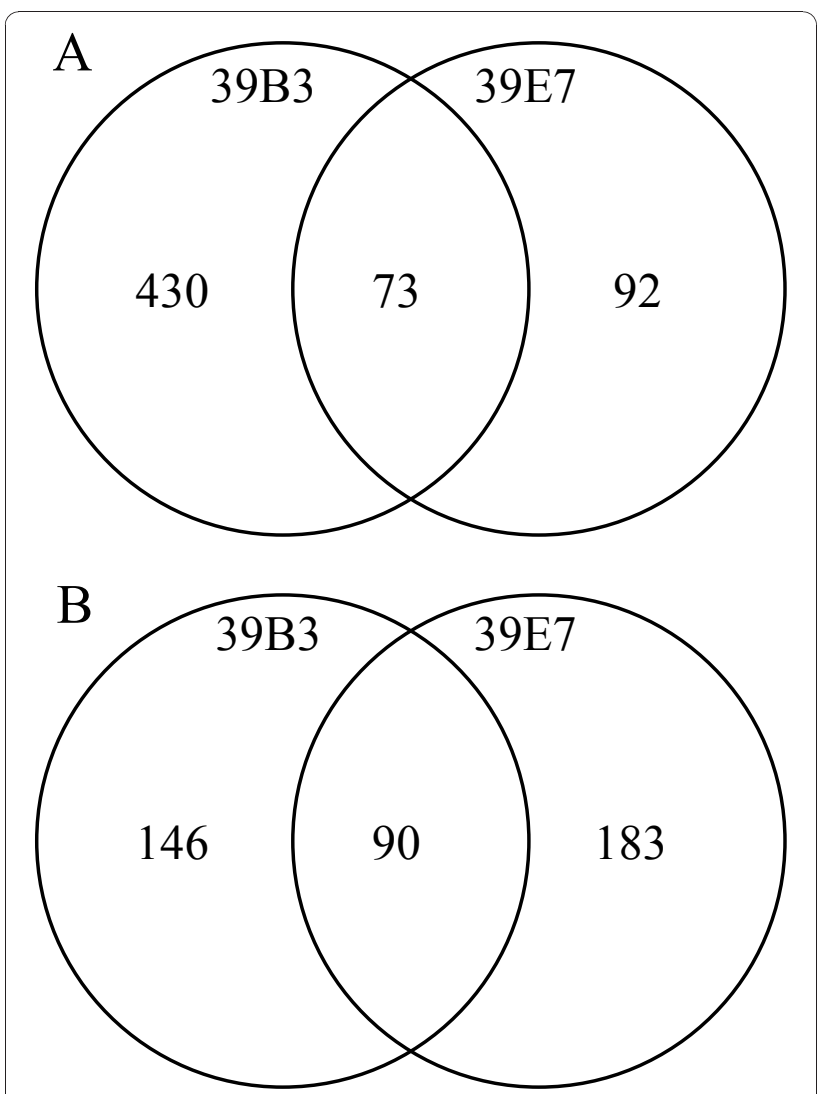

Figure 2 Transcriptomic analysis of flavedo from $39 \mathrm{~B} 3$ and $39 E 7$ mutants. Venn diagrams showing the number of common cDNAs up (A) and down-regulated (B) in flavedo excised from fruits harvested in November from 39B3 and 39E7.

ratios and false discovery rates of selected genes have been included as supplementary material in Additional file 1. As shown in Figure 2 from the 503 and 165 cDNAs overexpressed in 39B3 and 39E7 mutants, respectively, 73 were common. Similarly, a relatively high percentage of downregulated cDNAs were shared by 39B3 and 39E7 flavedos (90 from 236 and 273, respectively). The occurrence of common transcripts confirms the alteration of particular transcriptional programs in both mutants, which could be revealed by data mining of these coincident clones. None of the $90 \mathrm{cDNAs}$ that were found to be simultaneously down-regulated in both mutants were coincident with the known deleted genes of 39B3 and 39E7. Therefore, they are not expected to reduce their expression as a consequence of their occurrence in a genomic deletion. However, additional deletions to those reported in the published structural characterization of the 39B3 and $39 E 7$ hemizygous deletions [20] might occur in the genome of these mutants and consequently we cannot elucidate whether or not a certain down-regulated gene is included in a deleted fragment.
Functional classification of cDNAs differentially expressed in both 39B3 and 39E7 mutants highlighted major biochemical features underlying peel colour progression (Table 2 and 3). Thus, "photosynthesis" was one of the pivotal enriched categories in the mutants due to the presence in flavedo of photosynthetically active green chloroplasts. Several cDNAs coding for proteins involved in light harvesting, photosynthetic electron transfer chain, Calvin cycle and chlorophyll biosynthesis were overexpressed in mutant samples (Table 2), while no "photosynthesis" category could be created in the list of underexpressed cDNAs (Table 3).

Similarly, known biochemical and physiological features of citrus fruit flavedo at an advanced maturation stage, such as substitution and accumulation of secondary metabolites and cell wall degradation properly correlated with the enrichment and large size of the functional category "metabolism" and to a lesser extend with the category of "cell wall modification" (Table 2 and 3). For example, a valencene synthase responsible for the accumulation of valencene, an important sesquiterpene in the aroma of ripened citrus fruits [23], is catalogued as a down-regulated gene (Table 3). Conversely, a $\gamma$-terpinene synthase, involved in the biosynthesis of the monoterpene $\gamma$-terpinene in immature green fruits [24], is in the list of up-regulated genes (Table 2).

Interestingly, the transcriptomic study revealed that colour change appears to be also highly dependent upon a major transport activity. The most striking and novel observation in this regard was the high number of putative transporters of mineral elements and metals included in the functional category of "transport" that were down-regulated in the green flavedo of both mutants (Table 3). Thus, several sulfate and nitrate transporters, including a membrane transporter NRT1.2 implicated in chloride homeostasis [25], generic metal membrane transporters and specific zinc transporters were common in this category, suggesting that the mobilization of mineral elements such as sulfur, nitrogen, chloride, zinc and other metals may play a relevant role in flavedo ripening. The presence of a gene coding for a ferritin-like protein in the listing of down-regulated cDNAs ([GenBank:CX307912]; Table 3) may exemplify the relevance of these transporters in the colour-break flavedo. Plant ferritins have been described as chloroplastic and mitochondrial proteins involved in Fe(II) oxidation and Fe(III) storage, protecting the cells from the oxidative damage caused by reactive oxygen species produced by free iron $[26,27]$. For instance, limited iron availability in Chlamydomonas reinhardtii has been postulated to induce ferritin coding genes in order to buffer iron released by the degradation of photosystem I (PSI), an important sink for this metal [28]. Similarly, a related ferritin-like gene, up-regulated during leaf senescence in 
Table 2 Genes up-regulated during colour change in the flavedo of both 39B3 and 39E7 mutant fruit

\begin{tabular}{|c|c|c|c|c|c|}
\hline GenBank & EST & Description & GenBank & EST & Description \\
\hline Photosyntesis & & & Transport & & \\
\hline CX296851 & C05803E06 & Sedoheptulose-bisphosphatase & CX296724 & C05802B02 & ChaC-like family protein-like \\
\hline FC868525 & C31001E04 & Sedoheptulose-bisphosphatase & FC924529 & C31807B06 & Predicted protein \\
\hline FC875746 & C31301D05 & $\begin{array}{l}\text { LHCII type III chlorophyll a/b binding } \\
\text { protein }\end{array}$ & CX305822 & C18010F11 & T15F16.6 protein \\
\hline FC923644 & C31707D09 & $\begin{array}{l}\text { LHCII type III chlorophyll a/b binding } \\
\text { protein }\end{array}$ & CX297083 & C05808E01 & ChaC-like family protein-like \\
\hline FC875435 & C31403H07 & Oxygen evolving enhancer protein 1 & FC923446 & C31705B04 & At4g31290 \\
\hline FC920419 & C32008B06 & Chlorophyll a/b-binding protein CP24 & FC874940 & C31502E08 & $\begin{array}{l}\text { Putative mitochondrial dicarboxylate } \\
\text { carrier protein }\end{array}$ \\
\hline CX287330 & C01008D03 & Ultraviolet-B-repressible protein & DY300689 & KNOAAQ10YP18 & Putative cation transporter \\
\hline FC868970 & C31007B05 & Photosystem II protein psbY-2 & \multicolumn{2}{|c|}{ Response to pathogens } & \\
\hline CX288326 & C01019C02 & Chlorophyll a/b binding protein CP29.3 & & & \\
\hline CX288182 & C01017F05 & Photosystem I reaction center subunit VI & DY279218 & ICOAAA48DB11 & Putative thaumatin-like protein \\
\hline CX287508 & C01010C11 & Chlorophyll a/b binding protein 8 & FC875060 & C31503G11 & Disease resistance protein putative \\
\hline CX295423 & C05072A10 & Photosystem I subunit $X$ & \multirow{2}{*}{\multicolumn{2}{|c|}{ Calcium binding }} & \\
\hline CX296317 & C05138G04 & Photosystem I subunit XI & & & \\
\hline CX304424 & C16011F11 & Expressed protein & CX297244 & C05810C07 & Avr9/Cf-9 rapidly elicited protein 20 \\
\hline DY260996 & KNOAAP1YE17 & Chlorophyllide a oxygenase & DY261949 & KNOAAP4YI13 & Regulator of gene silencing \\
\hline \multicolumn{2}{|l|}{ Metabolism } & & \multicolumn{2}{|c|}{ ATP binding } & \\
\hline CX307598 & C19009B12 & $\begin{array}{l}\text { Xyloglucan endotransglucosylase/ } \\
\text { hydrolase }\end{array}$ & DY261553 & KNOAAP3YE02 & $\mathrm{F} 9 \mathrm{H} 16.5$ protein \\
\hline FC875561 & C31405C08 & Homocysteine S-methyltransferase & \multicolumn{2}{|c|}{ Redox homeostasis } & \\
\hline FC919748 & C08035D05 & Syringolide-induced protein 19-1-5 & & & \\
\hline FC923462 & C31705C11 & Aminotransferase 2 & FC923741 & C31708D11 & F1N19.7 \\
\hline FC924391 & C31805F07 & Glycosyl transferase-like protein & Others & & \\
\hline CX295258 & C05070C12 & Gamma-terpinene synthase & & & \\
\hline FC919842 & C08036D06 & $\begin{array}{l}\text { Arabidopsis thaliana genomic DNA } \\
\text { chromosome } 3 \text { TAC clone:K24A2 }\end{array}$ & CX297093 & C05808F01 & no annotation available \\
\hline CX292608 & C04017E11 & Terpene synthase & CX301234 & C08007E01 & no annotation available \\
\hline CX290116 & C02020F07 & Beta-amylase & FC868898 & C31006C04 & no annotation available \\
\hline DY272163 & ICOAAA30BF05 & Neutral invertase like protein & FC924593 & C31807H02 & no annotation available \\
\hline \multicolumn{3}{|c|}{ Regulation of transcription } & FC924767 & C31809G10 & no annotation available \\
\hline CX297352 & C05811E08 & no annotation available & & & \\
\hline FC875957 & C31303G04 & $\begin{array}{l}\text { Ethylene-responsive element binding } \\
\text { protein ERF4 }\end{array}$ & CX296215 & C05136C02 & Lectin like protein \\
\hline FC877608 & C31603G11 & zinc finger (CCCH-type) family protein & CX308197 & C20007C05 & $\begin{array}{l}\text { Arabidopsis thaliana genomic DNA } \\
\text { chromosome } 5 \text { TAC clone:K17N15 }\end{array}$ \\
\hline FC923229 & C31702D12 & $\begin{array}{l}\text { YABBY-like transcription factor } \\
\text { GRAMINIFOLIA }\end{array}$ & CX290048 & $\mathrm{C} 02019 \mathrm{H} 10$ & no annotation available \\
\hline FC923837 & C31709D11 & Salt-tolerance protein & CX303737 & C16002A07 & no annotation available \\
\hline DY273168 & ICOAAA33AG03 & $\begin{array}{l}\text { Putative glycine-rich zinc-finger DNA- } \\
\text { binding protein }\end{array}$ & FC923410 & C31704G03 & Expressed protein \\
\hline FC932314 & C34207C06 & Putative ethylene response factor 5 & FC923118 & C31701C08 & Putative nematode-resistance protein \\
\hline CX300605 & C07012B10 & Emb|CAA19725.1 & CX299915 & C07004A01 & Auxin-binding protein ABP19a precursor \\
\hline DY260986 & KNOAAP1YE03 & $\begin{array}{l}\text { Dehydration-responsive element binding } \\
\text { protein } 3\end{array}$ & CX301008 & C08004F12 & UVI1 \\
\hline DY261523 & KN0AAP3YC17 & $\begin{array}{l}\text { Contains similarity to ethylene responsive } \\
\text { element binding factor }\end{array}$ & FC931522 & C34106A06 & no annotation available \\
\hline \multicolumn{3}{|c|}{ Protein biosynthesis and modification } & DY283810 & IC0AAA5CD09 & $\begin{array}{l}\text { Arabidopsis thaliana genomic DNA } \\
\text { chromosome } 5 \text { TAC clone:K18I23 }\end{array}$ \\
\hline DY261222 & KNOAAP2YC12 & T17B22.3 protein & & & \\
\hline FC932340 & C34207E11 & Translation initiation factor-like protein & CX290835 & C02027F11 & expressed protein \\
\hline CX306680 & C18016F10 & T13D8.8 protein & FC924819 & C31810D08 & no annotation available \\
\hline FC875494 & C31404E10 & Putative RING-H2 finger protein & DY258718 & KNOAAI3AG02 & no annotation available \\
\hline \multirow[t]{2}{*}{ DY276175 } & ICOAAA40BG02 & T13D8.8 protein & DY261234 & KN0AAP2YD02 & AT5g08050/F13G24_250 \\
\hline & & & DY261435 & KNOAAP2YN14 & At1g21010 \\
\hline
\end{tabular}


Brassica napus, has been proposed to be involved in mobilization of iron from senescing cells to developing organs, where the metal is highly required [29]. Thus, ferritin accumulation in clementine flavedo tissue undergoing colour break may apparently contribute to the sequestering and recycling of iron molecules released during the degradation of photosystems and light-harvesting complexes, at the transition from chloroplast to chromoplast. The membrane transporters listed in Table 3 could initiate subsequent mobilization of the sequestered iron and maybe other metals and mineral elements to the cells requiring them.

The category of "transport" was also enriched with cDNAs coding for other several kinds of transporters including $\mathrm{ABC}$ transporters, sugar and protein transporters, aquaporin, $\mathrm{H}^{+}$-ATPases and other unidentified membrane transporters associated with the green stage of the flavedo (Table 3).

\section{A MYB-related transcription factor down-regulated in $39 \mathrm{~B} 3$ and $39 \mathrm{E} 7$}

Whereas nine different cDNAs coding for transcriptional regulators, including three ethylene response factors, were up-regulated in 39B3 and 39E7 (Table 2), only one was down-regulated in both mutants ([GenBank:CX287481]; Table 3). This transcription factor belongs to a subgroup of the GARP (GOLDEN2, ARR-B and Psr1) subfamily of MYB-related proteins containing a coiled-coil domain, which has been recently designated GCC (GARP and coiled-coil) [30,31]. Consequently, we named the protein deduced from this cDNA CcGCC1 (for Citrus clementina GCC). This gene was not found in a previous genomic approach to identify deleted genes in 39B3 and 39E7 mutants [20], and hence no gene dosage effects are expected to contribute to lower its expression in the mutants.

The partial sequence of CcGCC1 cDNA annotated in clone [GenBank:CX287481] was completed by sequencing its 3' end. The resulting nucleotide and amino acid sequences are shown in Figure 3. Database similarity search by BLASTP analysis [32] of the 233 residues long protein deduced from the cDNA confirmed a high similarity to other members of the GCC subgroup. We used the SMART [33] and COILS [34] applications to localize the GARP DNA-binding and the coiled-coil domains respectively, which are highlighted in Figure 3.

In order to compare $C c G C C 1$ and other related citrus ESTs with known members of this GCC subgroup, we selected a 90 amino acids long fragment fusing GARP and coiled-coil domains of CcGCC1 and several homologous proteins and translated ESTs [35-41]. The phylogenetic tree of these proteins showed two major groups with CcGCC1 clustered with PHR1 from Arabidopsis thaliana, a protein involved in phosphate starvation signalling (Figure 4). The closest homolog to CcGCC1 among those polypeptides was [GenBank:AAT06477], coded by At5g06800 gene from Arabidopsis. Interestingly, a search into the AtGenExpress database containing microarray expression data of Arabidopsis genes revealed that At5g06800 is mostly expressed in tissues lacking chloroplasts such as roots and to a lesser extent pollen and flower organs [42].

\section{CCGCC1 expression correlates with colour change processes}

In order to investigate the time-dependent expression of CcGCC1 during fruit external maturation in clementine, flavedo tissues collected before (September), during (November) and after fruit colour break (January), were subject to RNA extraction and quantitative RT-PCR with $C c G C C 1$ specific primers. Figure $5 \mathrm{~A}$ shows that the expression level of CcGCC1 in clementine increased about 15-fold during flavedo ripening, while 39B3 mutant maintained low expression levels in November and only experienced a slight increase in January. A similar change on CcGCC1 expression was observed in 39E7 mutant when samples harvested in November were assayed (Figure 5B). These results confirmed that CcGCC1 gene expression was induced during colour break of clementine fruits whereas mutants 39B3 and 39E7 affected in the rate of colour break were unable to properly express the gene.

To determine if the expression of $C c G C C 1$ gene was also responsive to other factors modulating colour change, a further experiment using external applications of gibberellins was performed (Figure 6). Gibberellins (GA) operate as colour change retardants during fruit external maturation since GA application on green flavedo causes a significant delay in colour break $[14,15]$. Forty-two days after the first application, fruits treated periodically with gibberellin $\mathrm{A}_{3}$ showed a delay of about 10 colour units with respect to untreated fruits (Figure 6A). Interestingly, the GA-dependent retard in peel colour was accompanied by a parallel delay in CcGCC1 induction (Figure 6B). These results indicate that $C c G C C 1$ also responds to the GA-dependent pathway regulating flavedo ripening and taken together with the previous observations suggest the participation of CcGCC1 in a regulatory pathway acting in parallel or subsequently to colour break processes.

\section{Conclusions}

In this work, the citrus mutants 39B3 and 39E7 showing a delay in fruit colour change have been phenotypically characterized and used to identify through the analyses of their transcriptomes about 160 genes that were directly related to peel ripening. The results indicated that the 39B3 genotype exhibits a simple delay in the 
Table 3 Genes down-regulated during colour change in the flavedo of both $39 \mathrm{~B} 3$ and $39 \mathrm{E} 7$ mutant fruit

\begin{tabular}{|c|c|c|c|c|c|}
\hline GenBank & EST & Description & GenBank & EST & Description \\
\hline \multicolumn{3}{|l|}{ Metabolism } & \multicolumn{3}{|c|}{ Cell wall modification } \\
\hline CX287976 & C01015D11 & Carbonic anhydrase & CX297394 & C06001A06 & Alpha-expansin 3 \\
\hline CX289383 & C02012D12 & Alkaline alpha galactosidase I & DY264363 & ICOAAA14BD04 & Expansin precursor \\
\hline CX289985 & C02019C03 & Putative fatty acid elongase & DY267644 & ICOAAA22AB05 & Putative pectinesterase \\
\hline CX289992 & C02019C10 & Putative aldehyde dehydrogenase & DY295146 & ICOAAA87BH09 & Expansin precursor \\
\hline CX292422 & C04015E09 & Valencene synthase & DY270980 & KNOAAP8YH13 & Putative pectinesterase \\
\hline CX298153 & С06009B08 & Cuticle protein & \multicolumn{3}{|c|}{ Electron transport } \\
\hline CX299160 & C06019E08 & Valencene synthase & & & \\
\hline FC919684 & C08034F10 & Limonoid UDP-glucosyltransferase & CX292526 & C04016F10 & $\begin{array}{l}\text { Cytochrome P450 monooxygenase } \\
\text { CYP83A }\end{array}$ \\
\hline CX304487 & C16012D12 & 3-ketoacyl-CoA synthase & CX293805 & C04035G11 & Cytochrome P450-like protein \\
\hline CX305894 & C18011E08 & $\begin{array}{l}\text { HAD superfamily protein involved in } \mathrm{N} \text { - } \\
\text { acetyl-glucosamine catabolism-like }\end{array}$ & FC921929 & C06054A10 & Cytochrome P-450-like protein \\
\hline CX307823 & C20002D06 & SRG1 protein & FC919490 & C08032F02 & Cytochrome P450 \\
\hline FC924270 & C31804D03 & Cinnamoyl CoA reductase & FC874820 & C31501C06 & CYP82C1p \\
\hline FC920274 & C32006B10 & Glucosyl transferase putative; 93894-95315 & FC924343 & C31805B05 & CYP82C1p \\
\hline FC930126 & C34004A11 & Beta-ketoacyl-CoA synthase & FC932589 & С $34210 C 05$ & Cytochrome P450 82A3 \\
\hline FC930590 & C34009B09 & F3H7.17 protein & DY265052 & ICOAAA16BA02 & $\begin{array}{l}\text { Non-photosynthetic ferredoxin } \\
\text { precursor }\end{array}$ \\
\hline FC932420 & C34208D08 & 3-ketoacyl-CoA synthase & \multicolumn{3}{|c|}{ ATP binding } \\
\hline DY265709 & ICOAAA18AD10 & Cinnamyl-alcohol dehydrogenase 1 & & & \\
\hline DY268060 & ICOAAA23AF08 & $\begin{array}{l}\text { Anthranilate synthase alpha subunit } \\
\text { precursor }\end{array}$ & CX290765 & $\mathrm{C} 02026 \mathrm{H} 12$ & Salt-induced AAA-Type ATPase \\
\hline DY276411 & ICOAAA41AD01 & Fructose 16-biphosphate aldolase 1 & CX300783 & C08002B12 & $\begin{array}{l}\text { UPI0000494294; PREDICTED: DEAD } \\
\text { (Asp-Glu-Ala-Asp) box polypeptide } 48\end{array}$ \\
\hline DY286831 & ICOAAA66AF01 & $\begin{array}{l}\text { Triterpene UDP-glucosyl transferase } \\
\text { UGT71G1 }\end{array}$ & FC921067 & C32202G02 & AT3g50930/F18B3_210 \\
\hline \multicolumn{3}{|c|}{ Regulation of transcription } & \multicolumn{3}{|l|}{ Others } \\
\hline CX287481 & C01010A07 & Similarity to transfactor & CX289110 & C02009C04 & no annotation available \\
\hline \multicolumn{3}{|c|}{ Protein modification } & CX289891 & C02018C02 & no annotation available \\
\hline CX292534 & C04016G06 & no annotation available & & & \\
\hline CX291784 & $\mathrm{C} 04004 \mathrm{H} 05$ & Dbj|BAA78736.1 & CX293032 & C04026G07 & T6D22.10 \\
\hline CX297891 & C06006D01 & Prolylcarboxypeptidase-like protein & CX293318 & C04030C06 & no annotation available \\
\hline FC931174 & C34102C06 & T12M4.17 protein & CX293633 & $\mathrm{C} 04033 \mathrm{HO} 01$ & AT4g35240/F23E12_200 \\
\hline FC931272 & C34103D03 & sos2-like protein kinase & CX298494 & C06012G09 & 2-on-2 hemoglobin \\
\hline \multicolumn{3}{|l|}{ Transport } & CX299244 & C06020D09 & no annotation available \\
\hline FC921826 & $\mathrm{C} 06052 \mathrm{HO} 3$ & $\begin{array}{l}\text { DENN (AEX-3) domain-containing protein- } \\
\text { like }\end{array}$ & & & \\
\hline CX290491 & C02024G06 & PDR6 ABC transporter & CX300782 & C08002B11 & no annotation available \\
\hline CX298347 & C06011C03 & Nitrate transporter NRT1-2 & CX301411 & C08009D08 & At1g62790 \\
\hline CX298349 & C06011C05 & T23G18.9 & CX301571 & C08011C01 & no annotation available \\
\hline CX307567 & C19008G08 & $\begin{array}{l}\text { sulfate transporter identical to sulfate } \\
\text { transporter (Arabidopsis thaliana) Gl:2130944 }\end{array}$ & FC919388 & C08031E06 & no annotation available \\
\hline CX307912 & C20003E08 & Ferritin-3 chloroplast precursor & FC919585 & C08033F04 & Nodulin-like protein \\
\hline CX309058 & C21007H09 & Metal transport protein & CX305371 & C18004G07 & no annotation available \\
\hline FC874907 & C31502B11 & Aquaporin & CX305882 & C18011D07 & no annotation available \\
\hline FC875147 & C31504G02 & Plasma membrane H+ ATPase & CX305893 & C18011E07 & no annotation available \\
\hline FC924175 & C31803D02 & Sugar transporter-like protein & CX309162 & C18021D09 & no annotation available \\
\hline FC930103 & C34003G11 & Integral membrane protein putative & CX306953 & C18023G08 & Nodulin-like protein \\
\hline FC931689 & $\mathrm{C} 34107 \mathrm{H} 08$ & Putative sulfate transporter ATST1 & FC924238 & C31804A05 & no annotation available \\
\hline DY279356 & ICOAAA49AG01 & Nitrate transporter NRT1-5 & FC921148 & C32101F10 & Emb|CAB71107.1 \\
\hline DY280267 & ICOAAA50DA03 & F10K1.26 protein & FC921343 & $\mathrm{C} 32103 \mathrm{HO} 4$ & Nodulin-like protein \\
\hline DY281465 & ICOAAA54AA12 & Zinc transporter protein ZIP1 & FC930621 & C34009E05 & no annotation available \\
\hline DY284165 & ICOAAA60CE05 & Zinc transporter 4 chloroplast precursor & FC931278 & C34103D09 & At5g02580 \\
\hline
\end{tabular}


Table 3 Genes down-regulated during colour change in the flavedo of both 39B3 and 39E7 mutant fruit (Continued)

\begin{tabular}{|c|c|c|c|c|c|}
\hline DY260609 & KN0AAP13YB08 & $\begin{array}{l}\text { Arabidopsis thaliana genomic DNA } \\
\text { chromosome } 5 \text { P1 clone:MUF9 }\end{array}$ & FC930770 & $\mathrm{C} 34108 \mathrm{H} 02$ & Putative embryo-abundant protein \\
\hline \multicolumn{3}{|c|}{ Response to pathogens } & DY267109 & ICOAAA20CC02 & no annotation available \\
\hline DY283754 & ICOAAA5BG06 & Expressed protein & & & \\
\hline CX293128 & C04028A01 & Major allergen Pru ar 1 & DY286094 & ICOAAA64CB07 & no annotation available \\
\hline CX295757 & C05075E12 & HcrVf1 protein & DY260627 & KNOAAP13YCO2 & Flowering promoting factor-like 1 \\
\hline CX297392 & C06001A04 & Pathogenesis-related protein 10 & & & \\
\hline FC923487 & C31705F01 & Thaumatin-like protein isoform 2 & & & \\
\hline
\end{tabular}

rate of flavedo colouration, while 39E7 shows an additional altered pattern of carotenoid accumulation. We postulate that the yellowish colour of fully ripe 39E7 flavedo was due to a defective synthesis or accumulation of $\beta$-citraurin. Analyses of differentially expressed genes revealed that colour change during peel ripening was strongly associated with a major mobilization of mineral elements and other previously known metabolic and photosynthetic changes. Transcriptomic data also showed that expression of $C c G C C 1$ gene coding for a transcription factor containing GARP and coiled-coil domains, was strongly down-regulated in flavedo tissue of both mutants. Application of gibberellin to green fruits postponed colour break and abolish the induction of CcGCC1 expression. Taken together the results indicated that $C c G C C 1$ down-regulation correlated with a delay in colour break induced by genetic, developmental and hormonal cues.

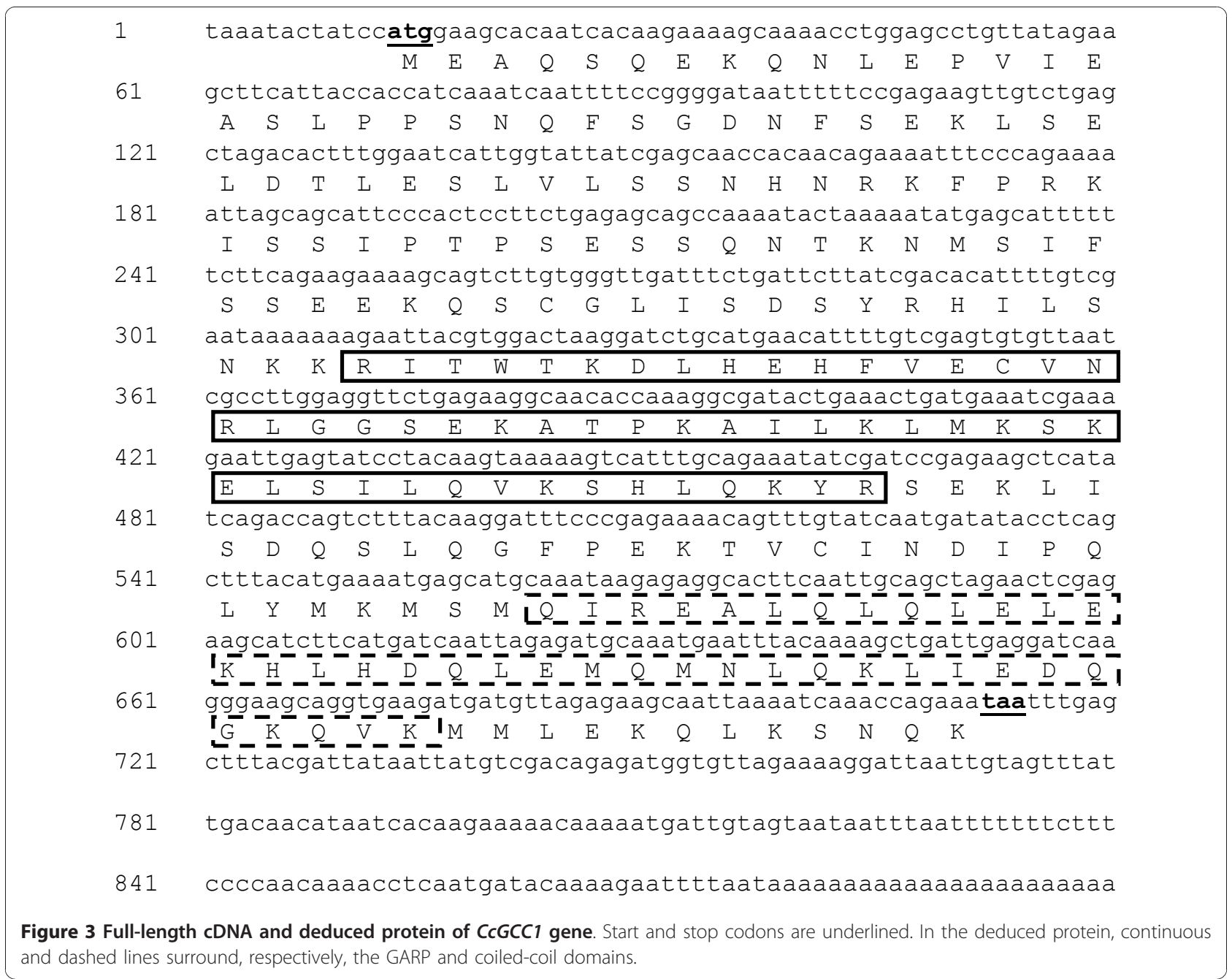




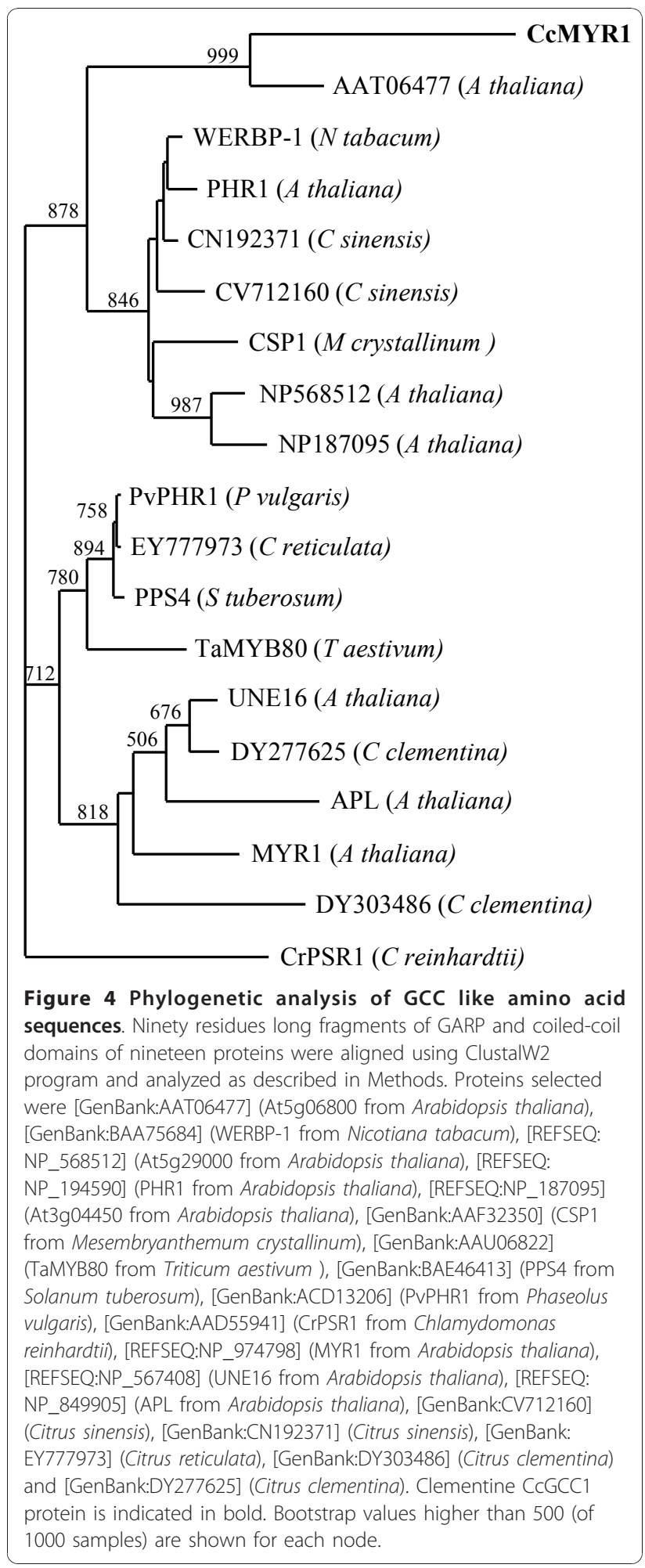

\section{Methods}

\section{Plant material}

About 7 years-old clementine trees (Citrus clementina Hort. Ex Tan. cv. clemenules) were grown at the

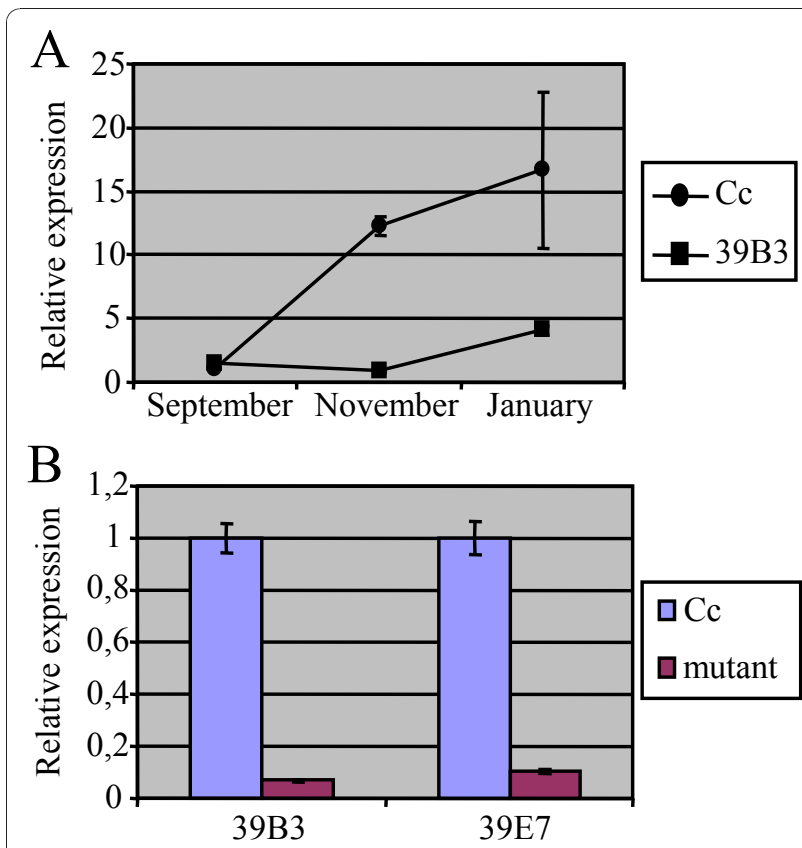

Figure 5 Expression analysis of CCGCC1 gene in flavedo during colour change. (A) Relative expression level of $\mathrm{CCGCCl}$ gene in flavedo from fruits of clementine (Cc) and 39B3 mutant at three developmental stages. In September, both clementine and 3983 show a green immature flavedo; in November, flavedo from clementine exhibits orange and yellowish colours while 39B3 flavedo is still green; and finally, in January, both genotypes show fully orange coloured flavedos. (B) Relative expression level of CCGCC1 gene in 3983 and $39 \mathrm{E} 7$ flavedos excised from fruits harvested in November. Vertical bars represent standard deviation.

Instituto Valenciano de Investigaciones Agrarias (IVIA) under standard agricultural practices. The 39B3 and 39E7 mutants were obtained by fast neutrons irradiation of clemenules buds [43].

\section{$\mathrm{GA}_{3}$ treatment}

Individually labelled fruits were periodically treated ontree with $60 \mathrm{mg} / \mathrm{L}$ gibberellin $\mathrm{A}_{3}\left(\mathrm{GA}_{3}\right)$ (Sigma). In each treatment, fruits on four adult trees were sprayed every 3 days from October 7 (189 days after anthesis) to November 18 (231 days after anthesis). After colour index determination (see below), flavedo tissue from treated and untreated trees was collected at three different dates: September 12 (previous to $\mathrm{GA}_{3}$ treatment), October 25 and November 18 [15].

\section{Colour index determination}

The L, $a$, and $b$ Hunter lab parameters of the colour system were measured on the flavedo surface with a Minolta CR-200 chromameter. The values presented are the results of the $1000 a / \mathrm{L} b$ transformation that results in negative and positive values for the green and orange colours, respectively, in citrus fruit [44]. In this 


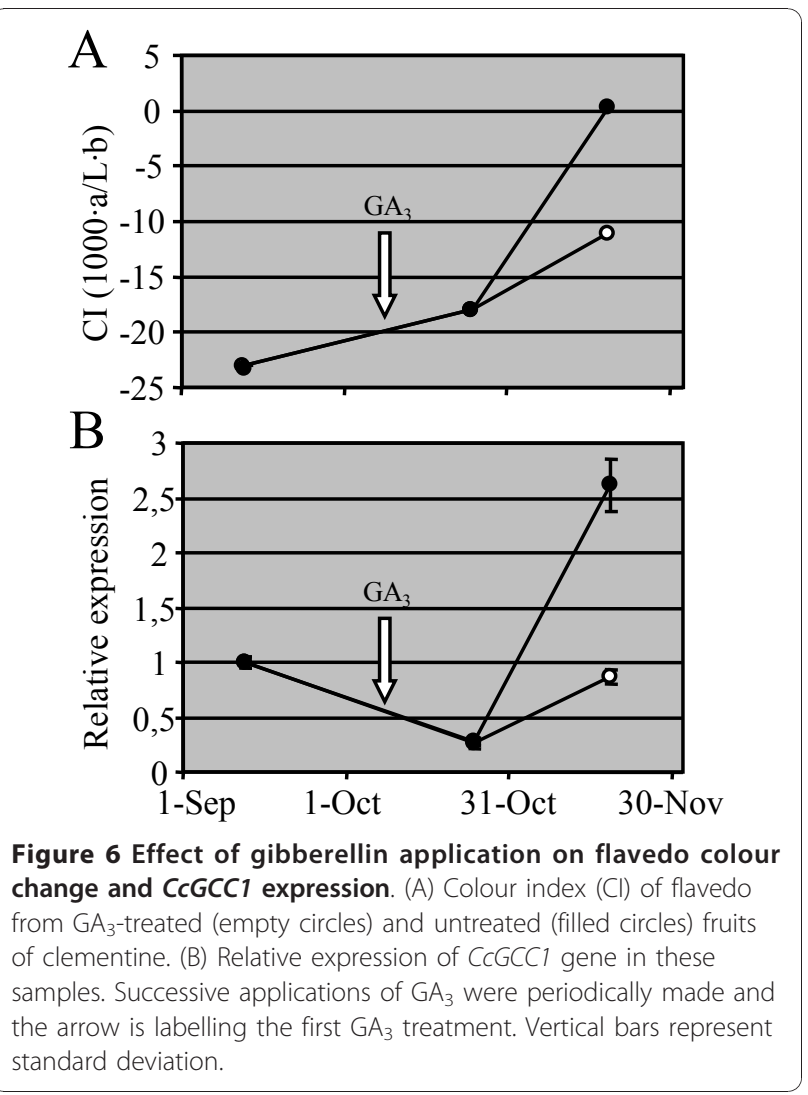

transformation, the zero value coincides with the midpoint of the colour break period. Eight and twenty fruits were measured per sample for the colour change curve and the GA experiment respectively.

\section{Extraction and quantification of chlorophylls and carotenoids}

Flavedo pigments were extracted as previously described [17]. Briefly, frozen ground material $(500 \mathrm{mg}$ ) of flavedo was extracted with a mixture of methanol and $50 \mathrm{mM}$ Tris- $\mathrm{HCl}$ buffer ( $\mathrm{pH} 7.5$ ) containing $1 \mathrm{M} \mathrm{NaCl}$ and partitioned against chloroform until plant material was uncoloured. The chlorophyll $(a+b)$ content was determined by measuring the absorbance of the extracts at $644 \mathrm{~nm}$ and $662 \mathrm{~nm}$ and calculated according to the Smith and Benitez equations [45]. After chlorophylls measurement, the pigment ethereal solution was dried and saponified using a $\mathrm{KOH}$ methanolic solution. The carotenoids were subsequently re-extracted with diethyl ether. Extracts were dried under $\mathrm{N}_{2}$ and kept at $-20{ }^{\circ} \mathrm{C}$ until HPLC analysis. Prior to HPLC analysis, carotenoid extracts were dissolved in acetone and incubated overnight at $-20^{\circ} \mathrm{C}$ to precipitate sterols that could interfere in the carotenoid analysis and subsequently dried under $\mathrm{N}_{2}$.

Carotenoid composition of each sample was analyzed by HPLC with a Waters liquid chromatography system equipped with a 600E pump and a model 996 photodiode array detector, and Empower software (Waters). A C30 carotenoid column $(250 \times 4.6 \mathrm{~mm}, 5 \mu \mathrm{m})$ coupled to a C30 guard column $(20 \times 4.0 \mathrm{~mm}, 5 \mu \mathrm{m})(\mathrm{YMC}$ Europe GMBH) was used. Samples were prepared for HPLC by dissolving the dried carotenoid extracts in $\mathrm{CHCl}_{3}: \mathrm{MeOH}$ : acetone (3:2:1, v:v:v). A ternary gradient elution with $\mathrm{MeOH}$, water and methyl tert-butyl ether (MTBE) was used for carotenoid separation reported in previous works $[17,46]$. Briefly, the initial solvent composition consisted of $90 \% \mathrm{MeOH}, 5 \%$ water and $5 \%$ MTBE. The solvent composition changed in a linear fashion to $95 \% \mathrm{MeOH}$ and 5\% MTBE at $12 \mathrm{~min}$. During the next 8 min the solvent composition was changed to $86 \% \mathrm{MeOH}$ and $14 \% \mathrm{MTBE}$. After reaching this concentration the solvent was gradually changed to $75 \% \mathrm{MeOH}$ and $25 \% \mathrm{MTBE}$ at $30 \mathrm{~min}$. Final composition was reached at $50 \mathrm{~min}$ and consisted of $50 \% \mathrm{MeOH}$ and $50 \%$ MTBE. Initial conditions were re-established in $2 \mathrm{~min}$ and re-equilibrated for $15 \mathrm{~min}$ before next injection. The flow rate was $1 \mathrm{~mL} / \mathrm{min}$, column temperature was set to $25^{\circ} \mathrm{C}$ and the injection volume was $20 \mu \mathrm{L}$. The photodiode array detector was set to scan from 250 to $540 \mathrm{~nm}$, and for each elution a Maxplot chromatogram was obtained, which plots each carotenoid peak at its corresponding maximum absorbance wavelength. Carotenoids were identified by comparison of the spectra and retention time with those of authentic standards, when available, or by matching the observed versus literature spectral data and retention time under identical chromatographic conditions $[12,46,47]$. The carotenoid peaks were integrated at their individual maxima wavelength and their content were calculated using calibration curves of $\beta$-apo-8'-carotenal (a gift from Hoffman-LaRoche) for apo- 8 -carotenal and $\beta$-citraurin, $\beta$-cryptoxanthin (Extrasynthese) for $\alpha$ - and $\beta$-cryptoxanthin, lutein (Sigma) for lutein, neoxanthin, violaxanthin isomers and mutatoxanthin, zeaxanthin (Extrasynthese) for zeaxanthin and antheraxanthin, and $\beta$-carotene (Sigma). Standards of phytoene, phytofluene and $\zeta$-carotene for quantification were obtained from flavedo extracts of Pinalate fruits, which accumulate large amounts of these compounds [17], and afterward purified by TLC.

Samples were extracted at least twice and each analytical determination was replicated at least once. All operations were carried out on ice under dim light to prevent photodegradation, isomerisations and structural changes of carotenoids.

\section{Expression profiling}

Total RNA was isolated from flavedo of clementine and mutant fruits collected in November, using RNeasy Plant Mini Kit (Qiagen). The transcripts present in $1.5 \mu \mathrm{g}$ of total RNA were reverse-transcribed, amplified 
and labelled with the Amino Allyl MessageAmp ${ }^{\text {tx }}$ II aRNA Amplification kit (Ambion), following the manufacturer's instructions. Cy3 and Cy5 fluorescent dyes coupled to the aRNA were obtained from the CyDye ${ }^{\mathrm{mm}}$ Post-Labeling Reactive Dye Pack (Amersham). Purified Cy5 and Cy3 labelled probes (200 pmol each) were combined, diluted with water to a final volume of $9 \mu \mathrm{L}$, and fragmented using the RNA Fragmentation Reagents (Ambion). Fragmented samples were heat-denatured for $2 \mathrm{~min}$ at $80^{\circ} \mathrm{C}$, mixed with $50 \mu \mathrm{L}$ of pre-heated hybridization buffer $(5 \times$ SSC, $50 \%$ formamide, $0.1 \%$ SDS, 0.1 $\mathrm{mg} / \mathrm{mL}$ salmon sperm DNA) and applied to the microarray slide prehybridized in $5 \times \mathrm{SSC}, 0.1 \% \mathrm{SDS}, 1 \% \mathrm{BSA}$, for at least $1 \mathrm{~h}$ at $42{ }^{\circ} \mathrm{C}$. We employed the $20 \mathrm{~K}$ Citrus cDNA microarrays containing 21240 EST generated by the Spanish Citrus Functional Genomics Project $[22,48,49]$. Three biological replicates of each mutant were compared to three replicates of control in a dyeswap experiment requiring six slides per mutant.

Hybridization was performed overnight at $42^{\circ} \mathrm{C}$. After hybridization, slides were washed 5 min twice at $42{ }^{\circ} \mathrm{C}$ in $2 \times \mathrm{SSC}, 0.1 \%$ SDS followed by two washes at room temperature for $5 \mathrm{~min}$ in $0.1 \times \mathrm{SSC}, 0.1 \% \mathrm{SDS}$, then by 5 washes at room temperature for $1 \mathrm{~min}$ in $0.1 \times$ SSC and rinsed briefly in $0.01 \times$ SSC before drying by centrifugation at $300 \mathrm{rpm} 5 \mathrm{~min}$.

Arrays were scanned at $5 \mu \mathrm{m}$. Cy3 and Cy5 fluorescence intensity was recorded by using a ScanArray Gx (Perkin Elmer). The resulting images were overlaid and spots identified by the ScanArray Express program (Perkin Elmer). Spot quality was first measured by the signal-to-background method with parameters lower limit (200) and multiplier (2), and subsequently confirmed by visual test. Data analysis was performed using the Limma package from the $\mathrm{R}$ statistical computing software [50]. A mutant/wild type signal higher than 2 or lower than 0.5 , with a P-value not higher than $10^{-5}$ were the cut-off values for positive EST identification. The 39B3 and 39E7 microarray experiments have been loaded into the ArrayExpress database under accessions E-MEXP-2638 and E-MEXP-2641, respectively.

\section{Quantitative RT-PCR}

Total RNA was isolated from excised flavedo using RNeasy Plant Mini Kit (Qiagen). RNA concentration was determined by a fluorometric assay with the RiboGreen dye (Molecular Probes) following the manufacturer's instructions. Five $\mu \mathrm{g}$ of total RNA was reverse transcribed with the SuperScript III First-Strand Synthesis System for RT-PCR (Invitrogen) in a total volume of $20 \mu \mathrm{L}$. Two $\mu \mathrm{L}$ of a 20 times diluted first-strand cDNA was used for each amplification reaction. Quantitative real-time PCR was performed on a LightCycler 2.0 instrument (Roche), using the LightCycler FastStart
DNA MasterPLUS SYBR Green I kit (Roche). Reaction composition and conditions followed manufacturer's instructions. The primers employed were 5'-CCGAGAAGTTGTCTGAGCTAGA-3' and 5'-CCCACAAGACTGCTTTTCTTCT-3', which amplified a fragment of 164 base pairs on a cDNA template. Cycling protocol consisted of $10 \mathrm{~min}$ at $95^{\circ} \mathrm{C}$ for pre-incubation, then 40 cycles of $10 \mathrm{sec}$ at $95^{\circ} \mathrm{C}$ for denaturation, $10 \mathrm{sec}$ at $60^{\circ} \mathrm{C}$ for annealing and $10 \mathrm{sec}$ at $72^{\circ} \mathrm{C}$ for extension. Fluorescent intensity data were acquired during the extension time. Specificity of the PCR reaction was assessed by the presence of a single peak in the dissociation curve after the amplification and through size estimation of the amplified product by gel electrophoresis. For expression measurements, we used the absolute quantification analysis from the LightCycler Software 4.0 package (Roche), and calculated expression levels relative to values of a reference sample. Reference sample was flavedo from the parental clementine in Figure 5 and flavedo tissue before GA application in Figure 6. Results were the average of 3 independent biological replicates repeated twice.

\section{Phylogenetic analysis}

The fused sequences of the GARP and coiled-coil domains of CcGCC1 and other 18 proteins obtained or deduced from databases were aligned with the ClustalW2 program [51]. Phylogenetic analysis was performed using programs from the PHYLIP.

group, PHYLogeny Inference Package, Version 3.6 [52,53]. A distance matrix was computed according to the Dayhoff PAM model by the program Protdist and then it was used as input for the program Neighbor, where the Neighbor-joining method of clustering was selected. A bootstrap analysis based on 1000 replicates was performed. CrPSR1 from Chlamydomonas reinhardtii was defined as the outgroup species.

\section{Additional material}

Additional file 1: Supplementary material. Log2 signal ratio $(M)$ and $P$ value of ESTs shown in Table 2 and 3 after microarray hybridization experiments.

\section{Acknowledgements}

Work was supported by grants AGL2007-65437-C04-01/AGR (Centro de Genómica) and AGL2009-11558 (L. Zacarías and M. J. Rodrigo) from the Ministerio de Educación y Ciencia of Spain. Assistance and technical expertise of A. Almenar, E Blázquez, I. López, I. Sanchís and M. Sancho from IVIA, and A. Beneyto from IATA are gratefully acknowledged.

\section{Author details}

${ }^{1}$ Centro de Genómica, Instituto Valenciano de Investigaciones Agrarias, Carretera Moncada-Náquera km 4.5, 46113 Moncada (Valencia), Spain.

${ }^{2}$ Departamento de Ciencia de Alimentos, Instituto de Agroquímica y 
Tecnología de Alimentos (IATA)-CSIC, Apartado de Correos 73, 46100 Burjassot (Valencia), Spain.

\section{Authors' contributions}

GR carried out transcriptomic and sequence analysis and drafted the manuscript. MAN carried out real-time PCR analyses. MJR and LZ performed pigments measurements and contributed to draft the manuscript. EA and MC designed and made the GA experiment. MT conceived the study and assisted in the drafting of the manuscript. All the authors read and approved the final manuscript.

Received: 21 May 2010 Accepted: 15 December 2010

Published: 15 December 2010

\section{References}

1. Bain JM: Morphological, anatomical, and physiological changes in the developing fruit of the Valencia orange, Citrus sinensis (L) Osbeck. Aust J Bot 1958, 6:1-23.

2. Gross J: Pigments in fruits London: Academic Press; 1987.

3. Tadeo FR, Cercos M, Colmenero-Flores JM, Iglesias DJ, Naranjo MA, Rios G, Carrera E, Ruiz-Rivero O, Lliso I, Morillon R, Ollitrault P, Talon M: Molecular physiology of development and quality of citrus. Adv Bot Res 2008, 47:147-223.

4. Iglesias DJ, Cercos M, Colmenero-Flores JM, Naranjo MA, Rios G, Carrera E, Ruiz-Rivero O, Lliso I, Morillon R, Tadeo FR, Talon M: Physiology of citrus fruiting. Braz J Plant Physiol 2007, 19:333-362.

5. Stewart I, Wheaton TA: Carotenoids in citrus. Their accumulation induced by ethylene. J Agric Food Chem 1972, 20(2):448-449.

6. Goldschmidt EE, Huberman M, Goren R: Probing the role of endogenous ethylene in the degreening of citrus fruit with ethylene antagonists. Plant Growth Regulation 1993, 12(3):325-329.

7. Iglesias DJ, Tadeo FR, Legaz F, Primo-Millo E, Talon M: In vivo sucrose stimulation of colour change in citrus fruit epicarps: Interactions between nutritional and hormonal signals. Physiol Plantarum 2001 112(2):244-250.

8. Trebitsh T, Goldschmidt EE, Riov J: Ethylene induces de novo synthesis of chlorophyllase, a chlorophyll degrading enzyme, in Citrus fruit peel. Proc Natl Acad Sci USA 1993, 90(20):9441-9445.

9. Jacob-Wilk D, Holland D, Goldschmidt EE, Riov J, Eyal Y: Chlorophyll breakdown by chlorophyllase: isolation and functional expression of the Chlase 1 gene from ethylene-treated Citrus fruit and its regulation during development. Plant Journal 1999, 20(6):653-661.

10. Azoulay Shemer T, Harpaz-Saad S, Belausov E, Lovat N, Krokhin O, Spicer V, Standing KG, Goldschmidt EE, Eyal Y: Citrus chlorophyllase dynamics at ethylene-induced fruit color-break: a study of chlorophyllase expression, posttranslational processing kinetics, and in situ intracellular localization. Plant Physiol 2008, 148(1):108-118.

11. Oberholster R, Cowan AK, Molnar P, Toth G: Biochemical basis of color as an aesthetic quality in Citrus sinensis. J Agric Food Chem 2001, 49(1):303-307.

12. Rodrigo MJ, Marcos JF, Zacarias L: Biochemical and molecular analysis of carotenoid biosynthesis in flavedo of orange (Citrus sinensis $\mathrm{L}$ ) during fruit development and maturation. J Agric Food Chem 2004, 52(22):6724-6731.

13. Kato $M$, Ikoma $Y$, Matsumoto $H$, Sugiura $M$, Hyodo $H$, Yano $M$ Accumulation of carotenoids and expression of carotenoid biosynthetic genes during maturation in citrus fruit. Plant Physio/ 2004, 134:824-837.

14. Rodrigo MJ, Zacarias $L$ : Effect of postharvest ethylene treatment on carotenoid accumulation and the expression of carotenoid biosynthetic genes in the flavedo of orange (Citrus sinensis L. Osbeck) fruit. Postharvest Biol Technol 2007, 43(1):14-22.

15. Alos E, Cercos M, Rodrigo MJ, Zacarias L, Talon M: Regulation of color break in citrus fruits. Changes in pigment profiling and gene expression induced by gibberellins and nitrate, two ripening retardants. J Agric Food Chem 2006, 54(13):4888-4895.

16. Alquezar B, Zacarias L, Rodrigo MJ: Molecular and functional characterization of a novel chromoplast-specific lycopene beta-cyclase from Citrus and its relation to lycopene accumulation. J Exp Bot 2009, 60(6):1783-1797

17. Rodrigo MJ, Marcos JF, Alferez F, Mallent MD, Zacarias L: Characterization of Pinalate, a novel Citrus sinensis mutant with a fruit-specific alteration that results in yellow pigmentation and decreased $A B A$ content. J Exp Bot 2003, 54(383):727-738.

18. Alos E, Roca M, Iglesias DJ, Minguez-Mosquera MI, Damasceno CMB, Thannhauser TW, Rose JKC, Talon M, Cercos M: An evaluation of the basis and consequences of a stay-green mutation in the navel negra citrus mutant using transcriptomic and proteomic profiling and metabolite analysis. Plant Physiol 2008, 147(3):1300-1315.

19. Distefano G, Las Casas G, Caruso M, Todaro A, Rapisarda P, La Malfa S, Gentile A, Tribulato E: Physiological and molecular analysis of the maturation process in fruits of Clementine Mandarin and one of its lateripening mutants. J Agric Food Chem 2009, 57(17):7974-82.

20. Rios G, Naranjo MA, Iglesias DJ, Ruiz-Rivero O, Geraud M, Usach A, Talon M: Characterization of hemizygous deletions in Citrus using arrayComparative Genomic Hybridization and microsynteny comparisons with the poplar genome. BMC Genomics 2008, 9:381

21. Farin D, Ikan R, Gross J: The carotenoid pigments in the juice and flavedo of a mandarin hybrid (Citrus reticulata) cv Michal during ripening. Phytochemistry 1983, 22(2):403-408.

22. Martinez-Godoy MA, Mauri N, Juarez J, Marques MC, Santiago J, Forment J, Gadea J: A genome-wide $20 \mathrm{~K}$ citrus microarray for gene expression analysis. BMC Genomics 2008, 3;9:318.

23. Sharon-Asa L, Shalit M, Frydman A, Bar E, Holland D, Or E, Lavi U, Lewinsohn E, Eyal Y: Citrus fruit flavor and aroma biosynthesis: isolation, functional characterization, and developmental regulation of Cstps1, a key gene in the production of the sesquiterpene aroma compound valencene. Plant J 2003, 36(5):664-674.

24. Shimada T, Endo T, Fujii H, Hara M, Ueda T, Kita M, Omura M: Molecular cloning and functional characterization of four monoterpene synthase genes from Citrus unshiu Marc. Plant Science 2004, 166(1):49-58.

25. Brumos J, Colmenero-Flores J, Conesa A, Izquierdo P, Sanchez G, Iglesias D, Lopez-Climent M, Gomez-Cadenas A, Talon M: Membrane transporters and carbon metabolism implicated in chloride homeostasis differentiate salt stress responses in tolerant and sensitive Citrus rootstocks. Functional \& Integrative Genomics 2009, 9(3):293-309.

26. Deak M, Horvath GV, Davletova S, Torok K, Sass L, Vass I, Barna B, Kiraly Z, Dudits D: Plants ectopically expressing the iron-binding protein, ferritin, are tolerant to oxidative damage and pathogens. Nat Biotechnol 1999, 17(2):192-196.

27. Ravet K, Touraine B, Boucherez J, Briat JF, Gaymard F, Cellier F: Ferritins control interaction between iron homeostasis and oxidative stress in Arabidopsis. Plant Journal 2009, 57(3):400-412

28. Busch A, Rimbauld B, Naumann B, Rensch S, Hippler M: Ferritin is required for rapid remodeling of the photosynthetic apparatus and minimizes photo-oxidative stress in response to iron availability in Chlamydomonas reinhardtii. Plant Journal 2008, 55(2):201-211.

29. BuchananWollaston V, Ainsworth C: Leaf senescence in Brassica napus: Cloning of senescence related genes by subtractive hybridisation. Plant Mol Biol 1997, 33(5):821-834.

30. Riechmann JL, Heard J, Martin G, Reuber L, Jiang C, Keddie J, Adam L, Pineda O, Ratcliffe OJ, Samaha RR, Creelman R, Pilgrim M, Broun P, Zhang JZ, Ghandehari D, Sherman BK, Yu G: Arabidopsis transcription factors: genome-wide comparative analysis among eukaryotes. Science 2000, 290(5499):2105-2110.

31. Nilsson L, Muller R, Nielsen TH: Dissecting the plant transcriptome and the regulatory responses to phosphate deprivation. Physiol Plant 2010, 139(2):129-143.

32. Altschul SF, Gish W, Miller W, Myers EW, Lipman DJ: Basic local alignment search tool. J Mol Biol 1990, 215(3):403-410

33. Schultz J, Milpetz F, Bork P, Ponting CP: SMART, a simple modular architecture research tool: identification of signaling domains. Proc Natl Acad Sci USA 1998, 95(11):5857-5864.

34. Lupas A, Van Dyke M, Stock J: Predicting coiled coils from protein sequences. Science 1991, 252(5010):1162-1164.

35. Rubio V, Linhares F, Solano R, Martin AC, Iglesias J, Leyva A, Paz-Ares J: A conserved MYB transcription factor involved in phosphate starvation signaling both in vascular plants and in unicellular algae. Genes Dev 2001, 15(16):2122-2133.

36. Patharkar OR, Cushman JC: A stress-induced calcium-dependent protein kinase from Mesembryanthemum crystallinum phosphorylates a twocomponent pseudo-response regulator. Plant J 2000, 24(5):679-691. 
37. Katou S, Yoshioka H, Kawakita K, Rowland O, Jones JD, Mori H, Doke N: Involvement of PPS3 phosphorylated by elicitor-responsive mitogenactivated protein kinases in the regulation of plant cell death. Plant Physiol 2005, 139(4):1914-1926.

38. Valdes-Lopez O, Arenas-Huertero C, Ramirez M, Girard L, Sanchez F, Vance $C P$, Reyes $J$, Hernandez G: Essential role of MYB transcription factor: PvPHR1 and microRNA: PvmiR399 in phosphorus-deficiency signalling in common bean roots. Plant Cell Environ 2008, 31(12):1834-1843.

39. Zhao C, Craig JC, Petzold HE, Dickerman AW, Beers EP: The xylem and phloem transcriptomes from secondary tissues of the Arabidopsis roothypocotyl. Plant Physiol 2005, 138(2):803-818.

40. Pagnussat GC, Yu HJ, Ngo QA, Rajani S, Mayalagu S, Johnson CS, Capron A, Xie LF, Ye D, Sundaresan V: Genetic and molecular identification of genes required for female gametophyte development and function in Arabidopsis. Development 2005, 132(3):603-614.

41. Bonke M, Thitamadee S, Mahonen AP, Hauser MT, Helariutta Y: APL regulates vascular tissue identity in Arabidopsis. Nature 2003, 426(6963):181-186

42. Schmid M, Davison TS, Henz SR, Pape UJ, Demar M, Vingron M, Scholkopf B, Weigel D, Lohmann JU: A gene expression map of Arabidopsis thaliana development. Nat Genet 2005, 37(5):501-506.

43. Franco FJ, Zong Y, de Agapito JA, Marques JG, Fernandes AC, CasasCubillos J, Rodriguez-Ruiz MA: Radiation tolerant D/A converters for the LHC cryogenic system. Nuclear Instruments and Methods in Physics Research Section A Accelerators, Spectrometers, Detectors and Associated Equipment 2005, 553(3):604-612.

44. Jiménez-Cuesta M, Cuquerella J, Martinez-Jávega JM: Determination of a color index for citrus fruit degreening. Proc Int Soc Citric 1981, 2:750-753.

45. Smith JHC, Benitez A: Chlorophylls. In Modern Methods of Plant Analyses. Edited by: Paech K, Tracey MV. Berlin: Springer; 1955:142-196.

46. Rouseff R, Raley L, Hofsommer H: Application of diode array detection with a $\mathrm{C}-30$ reversed phase column for the separation and identification of saponified orange juice carotenoids. J Agric Food Chem 1996, 44(8):2176-2181.

47. Britton G: UV/visible spectroscopy. In Carotenoids Volume 1B Spectroscopy Edited by: Britton G, Liaaen-Jensen S, Pfander H. Basel: Birkhäuser Verlag; 1995:13-63.

48. Forment J, Gadea J, Huerta L, Abizanda L, Agusti J, Alamar S, Alos E, Andres F, Arribas R, Beltran JP, Berbel A, Blazquez MA, Brumos J, Canas LA, Cercos M, Colmenero-Flores JM, Conesa A, Estables B, Gandia M, GarciaMartinez JL, Gimeno J, Gisbert A, Gomez G, Gonzalez-Candelas L, Granell A, Guerri J, Lafuente MT, Madueno F, Marcos JF, Marques MC, Martinez F, Martinez-Godoy MA, Miralles S, Moreno P, Navarro L, Pallas V, PerezAmador MA, Perez-Valle J, Pons C, Rodrigo I, Rodriguez PL, Royo C, Serrano R, Soler G, Tadeo F, Talon M, Terol J, Trenor M, Vaello L, Vicente O, Vidal C, Zacarias L, Conejero V: Development of a citrus genome-wide EST collection and cDNA microarray as resources for genomic studies. Plant Mol Biol 2005, 57(3):375-391.

49. Terol J, Conesa A, Colmenero JM, Cercos M, Tadeo F, Agusti J, Alos E, Andres F, Soler G, Brumos J, Iglesias DJ, Gotz S, Legaz F, Argout X, Courtois B, Ollitrault P, Dossat C, Wincker P, Morillon R, Talon M: Analysis of 13000 unique Citrus clusters associated with fruit quality, production and salinity tolerance. BMC Genomics 2007, 8:31.

50. Gentleman RC, Carey VJ, Bates DM, Bolstad B, Dettling M, Dudoit S, Ellis B, Gautier L, Ge YC, Gentry J, Hornik K, Hothorn T, Huber W, lacus S, Irizarry R, Leisch F, Li C, Maechler M, Rossini AJ, Sawitzki G, Smith C, Smyth G, Tierney L, Yang JYH, Zhang JH: Bioconductor: open software development for computational biology and bioinformatics. Genome Biol 2004, 5(10):R80.

51. Anonymous ClustalW2 at the European Bioinformatics Institute. [http:// www.ebi.ac.uk/Tools/clustalw2/index.html].

52. Anonymous Phylogeny programs (Institut Pasteur). [http://bioweb2. pasteur.fr/phylogeny/intro-en.html].

53. Felsenstein J: Confidence Limits on Phylogenies: An Approach Using the Bootstrap. Evolution 1985, 39(4):783-791.

doi:10.1186/1471-2229-10-276

Cite this article as: Ríos et al:: Identification of a GCC transcription factor responding to fruit colour change events in citrus through the transcriptomic analyses of two mutants. BMC Plant Biology 2010 10:276.

\section{Submit your next manuscript to BioMed Central and take full advantage of:}

- Convenient online submission

- Thorough peer review

- No space constraints or color figure charges

- Immediate publication on acceptance

- Inclusion in PubMed, CAS, Scopus and Google Scholar

- Research which is freely available for redistribution

Submit your manuscript at www.biomedcentral.com/submit 